\title{
EFEKTIFITAS TATA TERTIB DALAM MENGIMPLEMENTASIKAN NILAI -NILAI PENDIDIKAN ISLAM DI MTS MUHAMMADIYAH NUSA PUAN BUANO UTARA KABUPATEN SERAM BAGIAN BARAT
}

\author{
Hajar Hitimala \\ Program Studi Pendidikan Agama Islam FITK IAIN Ambon \\ email: $\underline{\text { Hajarhitimala@gmail.com. }}$
}

\begin{abstract}
Effectivitas is a series of activities carried out by teachers and students by utilizing available facilities to obtain optimal learning outcomes. The effectiveness of the order is a measure that states how far the quantity and quality targets have been achieved. In the process of implementing the rules at MTs Muhammadiyah Nusa Puan, various activities and lessons are carried out both inside and outside the classroom and with various methods, such as the lecture method, storytelling, discussion, and assignment method. This type of research is field qualitative and descriptive. Collecting data using interview, observation, and documentation methods. Test the validity of the data using source triangulation and time triangulation techniques. The data analysis technique that the researcher uses is data reduction, data presentation, and verification. The results of this study indicate that 1). the effectiveness of the rules in implementing the values of Islamic education at MTs Muhammadiyah Nusa Puan has been effective. As evidence that the process of discipline in Islamic values is effective, namely through the means and media used, as well as the attitude of students in taking responsibility for the advice given by the teacher. 2). supporting factors. (a. educators in implementing discipline in accordance with implementing Islamic educational values, b. educators, almost all of them can implement in appropriate disciplines, c. facilities and infrastructure, as evidenced by the school environment in order), 3) internal factors : (a. internal factors from students, some people understand the rules well, b. external factors, from the environment and society).
\end{abstract}

Keywords: order, the values of Islamic education.

Abstrak: Efektifitas merupakan serangkaian kegiatan yang dilaksanakan oleh guru dan peserta didik dengan memanfaatkan sarana yang tersedia untuk memperoleh hasil belajar secara optimal. Efektivitas tata tertib merupakan suatu ukuran yang menyatakan seberapa jauh target kuantitas maupun kualitas yang telah tercapai. Dalam proses pelaksanaan tata tertib di MTs Muhammadiyah Nusa Puan memuat berbagai kegiatan dan pelajaran baik yang dilaksanakan di dalam kelas maupun di luar kelas dan dengan berbagai macam metode, seperti metode ceramah, bercerita, diskusi, dan metode tugas. Jenis penelitian ini adalah kualitatif lapangan dan bersifat deskriptif. Pengumpulan data menggunakan metode wawancara, observasi, dan dokumentasi. Uji keabsahan data menggunakan teknik triangulasi sumber dan triangulasi waktu. Teknik analisis data yang Peneliti gunakan adalah reduksi data, penyajian data, dan verification. Hasil penelitian ini menunjukkan bahwa 1). efektivitas tata tertib dalam mengimplementasikan nilai-nilai pendidikan islam di MTs Muhammadiyah Nusa Puan sudah efektif. Sebagai bukti bahwa proses tata tertib pada nilai-nilai Islam itu efektif yaitu melalui, sarana dan media yang digunakan, serta sikap peserta didik dalam mempertanggungjawabkan nasehat yang diberikan oleh Guru. 2). faktor pendukung. (a. pendidik dalam menerapkan tata tertib sesuai dengan mengimplementasikan nilai-nilai pendidikan islam, b. pendidik, hampir semua dapat mengimplementasikan pada tata tertib yang sesuai, c. sarana dan prasarana, dibuktikan dengan lingkungan sekolah pada tata tertib), 3) faktor internal: (a. faktor internal dari peserta didik yang beberapa orang memahami tata tertib dengan baik, b. faktor external, dari lingkungan maupun masyarakat).

Kata kunci: tata tertib, nilai-nilai pendidikan islam. 


\section{PENDAHULUAN}

Pendidikan sebagai usaha manusia untuk menumbuhkan dan mengembangkan potensi-potensi pembawaan jasmani maupun rohani sesuai dengan nilai-nilai yang yang ada di dalam masyarakat dan kebudayaan. Pendidikan bagi kehidupan manusia merupakan kebutuhan mutlak yang harus dipenuhi sepanjang hayat. Tanpa pendidikan sama sekali mustahil suatu kelompok manusia dapat hidup berkembang sejalan dengan aspirasi (cita-cita) untuk maju, sejahtera dan bahagia menurut konsep pandangan hidup mereka (Fuad Ihsan, 2013:1-2).

Berdasarkan Undang-Undang SIKDIKNAS Nomor. 20 tahun 2003, yang menyatakan bahwa:"Pendidikan adalah usaha sadar dan terencana untuk mewujudkan suasana belajar agar peserta didik secara aktif mengembangkan potensi dirinya untuk memiliki kekuatan spiritual, keagamaan, pengendalian diri, kepribadian, kecerdasan, akhlak mulia, serta keterampilan yang diperlukan dirinya, masyarakat, bangsa dan Negara (UU SISDIKNAS, 2003:3)". Melalui paparan defenisi dan UndangUndang yang diuraikan maka bisa disimpulkan bahwa pendidikan adalah usaha sadar untuk mendidik serta mengajarkan sesuatu pada orang lain. Dari sinilah peneliti mulai mempelajari mengenai masalah-masalah yang terjadi di MTs Muhammdiyah Nusa Puan yang terletak di Negeri Buano Utara Kecamatan Huamual Belakang Kabupaten Seram Bagian Barat 
masalah yang terjadi diantara mengenai penerapan nilai-nilai Pendidikan Islam pada peserta didik ditunjukkan dalam bentuk kegiatan maupun dalam proses pelaksanaan belajar mengajar yang dilaksanakan di dalam kelas.

Setiap peserta didik mempunyai karakteristik yang berbeda sehingga, ada sebagian peserta didik yang melakukan hal-hal yang melenceng dari nilai-nilai keislaman dan juga ada yang melaksanakan sesuai dengan anjuran keislaman. Hal yang sering ditemukan seperti peserta didik yang menunjukan sikap seakan-akan tidak menghargai guru ketika guru memberikan pembelajaran baik ada Pendidikan Agama Islam maupun pembelajaran yang lain. Beda halnya dengan peserta didik yang selalu taat pada perintah guru dalam proses pembelajaran maupun pada tata tertib yang berlaku di MTs Muhammadiyah Nusa Puan.

Tata tertib madrasah dibuat dengan maksudnya agar warga madrasah diharapkan dapat mengembangkan pola sikap dan perilaku yang lebih disiplin dan produktif (Amin Wijaya Tunggal, 2010:8). Lahirnya tata tertib tersebut menjadikan warga madrasah memiliki pedoman dan acuan dalam melaksanakan kebijakan, program, dan kegiatan madrasah lainnya, maka madrasah memiliki tata tertib madrasah. Aktifitas pengendalian terhadap perilaku peserta didik yang dilakukan secara kontinyu oleh pimpinan madrasah secara maksimal akan membuat institusi menjadi sebuah lembaga yang memiliki kedisiplinan tinggi. Oleh karena itu, tata tertib madrasah harus disusun secara sistematik agar implementasi berjalan sesuai job description yang mengarah pada asas efisiensi dan efektivitas.

Fungsi pengendalian merupakan penentuan standar kerja dan hasil kerja, pengukuran kerja dan standarnya, serta pengambilan tindakan. Inilah sesungguhnya esensi dari adanya pengendalian tata tertib madrasah.Tata tertib peserta didik sangat penting sebagai aturan yang harus dipatuhi oleh peserta didik, bahkan setiap kelas dapat membuat tata tertib sendiri untuk kelasnya masing-masing. 
Perilaku peserta didik perlu dengan bimbingan dan dikendalikan agar tidak terjadi perilaku menyimpang karena peserta didik merupakan individu yang sedang tumbuh dan berkembang serta memasuki masa yang rawan (Desmita, 2004;39-40). Hal ini dilakukan agar tidak berakibat fatal dan merugikan baik bagi individu itu sendiri atau bagi orang lain. Bimbingan tersebut dapat berupa pengendalian yang dilakukan oleh madrasah terhadap peserta didik untuk mencegah terjadinya perilaku menyimpang. Dalam organisasi suatu lembaga pendidikan, manusia atau dalam hal ini (peserta didik) merupakan variabel yang harus diarahkan, dituntun, dan dimotivasi untuk mencapai tujuan. Kegagalan pengendalian bisa terjadi karena kurang konsisten dalam menghadapi peserta didik. Sikap konsisten dianggap sebagai dasar pengendalian peserta didik yang efektif. Pada umumnya bila fondasi itu kuat, kemungkinan besar bangunan yang didirikan di atasnya akan baik, tetapi jika fondasinya rapuh, akan timbul banyak masalah. Dengan sikap konsisten, kemungkinan besar akan berhasil menerapkan proses pengendalian itu. Di lain pihak, pendekatan yang tidak konsisten dalam pengendalian peserta didik hampir pasti akan menjurus pada kegagalan (Mallary Collins, 2003:11-12).

\section{METODE}

Jenis penelitian ini adalah pendekatan deskriptif kualitatif yaitu suatu prosedur penelitian yang menghasilkan data deskriptif berupa ucapan atau tulisan dan perilaku yang dapat diamati dari orang (subyek) itu sendiri. Dengan pendekatan penelitian kualitatif ini, peneliti akan membuat deskripsi tentang gambaran objek yang diteliti secara sistematis, baik itu mengenai fakta-fakta, sifat-sifat serta berbagai hal yang terkait dengan tema penelitian. Pendekatan kualitatif ini digunakan karena data yang dibutuhkan berupa lembaran-lembaran informasi yang tidak perlu dikualifikasikan. Dimana dalam penelitian ini peneliti akan menghimpun informasi terkait dengan ektivitas dalam mengimplementasikan nilai-nilai 
pendidikan di madrasah MTs Muhammadiyah Nusa Puan Negeri Buano Utara Kabupaten Seram Bagian Barat.

Penelitian deskriptif merupakan penelitian terhadap fenomena atau populasi tertentu yang diperoleh peneliti dari subyek berupa individu, organisasi, industri atau prespektif yang lain. Adapun tujuannya adalah untuk menjelaskan aspek-aspek yang relevan dengan fenomena yang diamati, menjelaskan karakteristik atau masalah yang ada.

\section{HASIL}

\section{Efektivitas Peserta didik di MTs Muhammadiyah Nusa Puan}

Seorang guru selain bertugas mentransfer materi pembelajaran, ada hal yang lebih subtantif dan signifikan untuk dilakukan, yakni memberi pemahaman kepada peserta didik tentang makna atau nilai-nilai yang terkandung dalam materi pembelajaran yang diajarkan tersebut serta penegasan tentang pemahaman tata tertib yang ada di madrasah. Tugas penting ini harus dilakukan oleh setiap guru, harus memberikan motivasi, arahan, dan keteladanan kepada peserta didik dalam mengikuti pembelajaran di kelas sehingga efektivitas belajar peserta didik dapat tercapai.

Dalam kaitannya dengan efektivitas peserta didik di MTS Muhammadiyah Nusa Puan, Desa Buano Utara Kecamatan Huamual Belakang, Kabupaten Seram Bagian Barat, dari hasil pengamatan peneliti selama melakukan penelitian bahwa Efektifitas tata tertib sudah baik hal ini sudah baik indikatornya dapat dilihat selama proses pembelajaran di kelas baik guru maupun peserta didik sesuai dengan aturan yang telah ditetapkan. Hal ini sebagaimana yang diungkapkan oleh informan dari guru yang peneliti wawancarai mengungkapkan:

"Bahwa untuk mengefektifkan proses pembelajaran maka saya selaku guru senantiasa mempersiapkan materi pembelajaran dengan menggunakan media, selain itu dalam pertemuan sebelumnya saya sudah informasikan kepada peserta didik tentang materi pembelajaran berikutnya yang akan dipelajari agar peserta didik mempelajarinya dirumahnya, sehingga waktu yang digunakan dalam menjelaskan materi tidak terlalu lama karena dengan 
bantuan media, sehingga waktu saya gunakan seefisen dan seefektif mungkin, hal ini akan berdampak peserta didik dapat memahami materi yang saya sampaikan"

Hal senada juga disampaikan oleh informan dari peserta didik yang peneliti wawancarai mengungkapkan:

"Bahwa di MTs Muhammadiyah Nusa Puan dalam proses pengenalan tata tertib sangat efektif ini dapat di lihat bahwa setiap guru yang masuk mengajar sesuai dengan waktu yang telah ditentukan dan keluar dengan sesuai dengan waktu yang ada. Selain itu menurut saya bahwa guru-guru dalam proses pengenalan tata tertib senantiasa untuk membantu pihak madrasah, dalam mendidik peserta didik."

Dalam upaya meningkatkan efektivitas peserta didik melakukan berbagai macam strategi, metode maupun pendekatannya. Strategi pembelajaran yang dilakukan oleh guru MTs Muhammadiyah Nusa Puan. dalam upaya peningkatan efektifitas peserta didik di MTs Muhammadiyah Nusa Puan dilakukan dalam tiga tahapan, yakni tahapan pelaksanaan nasehat, keteladanan dan pembiasaan.

Adapun strategi, metode maupun pendekatan yang dilakukan pada saat peserta didik melakukan pelanggaran adalah:

a. Pemberian Nasihat

Islam sangat menganjurkan kepada umatnya untuk saling nasihat menasehati antar sesama. Menurut pengamatan dan hasil wawancara peneliti, salah satu upaya yang dilakukan guru MTs Muhammadiyah Nusa Puan dalam rangka menerapkan tata tertib pada peserta didik adalah melalui strategi pemberian nasehat. Pemberian nasehat biasanya dilakukan pada awal pembelajaran. Hal ini seperti yang dikatakan guru Bimbingan Konseling sebagai berikut:

" sebelum proses pembelajaran di mulai terlebih dahulu, guru mengigatkan peserta didik pada tata tertib yang di terapkan MTs Muhammadiyah Nusa Puan, sehingga peserta didik taat dan patuh pada aturan tersebut, bukan hanya itu efektifitas peserta didik dalam menjalankan tata tertib pun cukup di bilang bagus" 
Berdasarkan ungkapan yang diuraikan oleh guru BK dapat disimpulkan bahwa, peserta didik sebelum melaksanakan pembelajaran, peserta didik terlebih dahulu diberikan nasehat, agar peserta didik selalu patuh pada aturan yang diterapkan di MTs Muhammadiyah Nusa Puan, bukan hanya sekedar patu pada aturan namun, peserta didik juga mengaplikasikan tata tertib itu di lingkungannya.

Materi yang menjadi isi muatan nasehat biasanya berkaitan dengan mengingatkan akan pentingnya melakukan salat, terutama salat yang dilaksanakan di luar jam belajar, berkaitan dengan tata Krama bergaul dengan orang tua, tata Krama dengan para guru dan juga nasehat yang berupa motivasi-motivasi lain yang berkaitan masa depan peserta didik.

Strategi yang dilaksanakan dalam pemberian nasehat ini biasanya dengan terlebih dahulu menanyakan, hal-hal yang berkaitan dengan kepribadian peserta didik. Peneliti juga perlu menyampaikan bahwa selama pengamatan peneliti, dan hasil wawancara dengan peserta didik, dan guru yang ada di MTs Muhammadiyah Nusa Puan. Hal ini terjadi karena ia menyadari fungsi dan perannya sebagai seorang guru menyadari.

b. Keteladanan

Pemberian keteladanan oleh para guru terhadap peserta didik dalam menerapkan tata tertib ini dapat dilihat dari pengamatan peneliti bahwa guru datang tepat waktu, mengajar tempat waktu dan berpakaian rapi. Keteladanan menjadi salah satu strategi yang efektif ditekankan oleh kepala madrasah kepada para guru dalam melaksanakan tugas pembelajarannya, baik di dalam pembelajaran maupun di luar pembelajaran.

c. Pembiasaan

Pembiasan yang dimaksud penulis adalah upaya yang berbentuk kegiatan yang dilakukan oleh guru Mts Muhammadiyah Nusa Puan kepada semua peserta didik yang di dalamnya mengandung tata tertib. 
Pembiasaan ini tidak hanya dilakukan oleh kepala madrasah, akan tetapi oleh semua guru yang berada di Madrasah ini, akan tetapi masing-masing guru biasanya memiliki karakter dan teknik yang berbeda walupun substansi tujuannya sama.

Pembiasaan yang biasa dilakukan sepengetahuan pengamatan penulis antara lain adalah budaya membersihkan sampah yang ada di sekitar kelas masing-masing peserta didik, mengucapkan salam apabila bertemu dengan guru baik di lingkungan madrasah maupun di luar lingkungan madrasah, berdoa bersama, sebelum memulai mata pelajaran dan selesai pelajaran terakhir yang dipimpin oleh ketua kelas, bersegera ketika dipanggil atau dimintai pertolongan oleh guru atau orang tua yang ada di sekitar lingkungan madrasah.

Dalam proses pengajaran, unsur proses belajar memegang peran yang sangat penting. Dalam menciptakan kondisi pembelajaran yang efektif di Mts Muhammadiyah Nusa Puan lebih menekankan kepada ketertiban dan kedisiplinan. Menurut Damsar bahwa pemeliharaan ketertiban berkaitan dengan kemampuan diri untuk tertib sesuai dengan konstruksi sosial dan hukum yang ada.

Sedangkan disiplin merupakan kemampuan diri untuk taat, patuh, dan berkomitmen untuk sesuai apa yang dipandang baik dan benar dalam konstruksi sosial, budaya, dan hukum (Damsar,2018:111). Hal ini sejalan dengan teori konvergensi menyatakan bahwa seseorang itu dipengaruhi oleh dua faktor yakni faktor bakat dan factor lingkungan. Dari hasil pengamatan dan wawancara yang peneliti lakukan proses pembelajaran di Madrasah Tsanawiyah berjalan dengan efektif.

Indikatornya adalah seluruh materi pembelajaran yang telah ditentukan oleh kurum dapat tercapai. Selain itu, dalam proses pembelajaran yang dilaksanakan oleh guru-guru berdasarkan hari-hari efektif tetap sesuai dengan koridor yang ada. Walaupun ada guru tidak hadir dalam proses pembelajaran atau dengan kata lain kelas kosong maka ke madrasah atau guru BK yang mengisinya. Serta yang tak kalah 
pentingnya yang mendukung efektifitas pembelajaran di MTS Muhammadiyah Nusa Puan adalah tersediannya sarana dan prasarana yang menunjang dalam proses pembelajaran baik itu sifat kurikuler maupun ekstra kurikuler.

\section{Upaya-Upaya yang Dilakukan Guru dalam menanamkan nilai-nilai pendidikan isIma pada peserta didik}

Arahan dari kepala Madrasah Tsanawiyah (MTs) Muhammadiyah Nusa Puan bahwa guru dalam melaksanakan kegiatan pembelajaran di kelas hendaknya senantiasa menekankan penerapan tata tertib di kelas sebelum proses pembelajaran dimulai. Dalam proses pembelajaran yang dilakukan oleh seorang guru dalam menciptakan kondisi belajar yang efektif maka yang diupayakan oleh guru dengan menekankan tata tertib yang dilakukan oleh seorang guru dalam proses pembelajaran.

Dalam menciptakan kondisi pembelajaran yang kondusif di Madrasah Tsanawiyah (MTs) Muhammadiyah Nusa Puan lebih menekankan kepada ke disiplinan dan mematuhi aturan yang diterapkan pihak madrasah kepada peserta didik, sebagaimana yang diungkapkan oleh informan yang peneliti wawancarai sebagai berikut:

Dalam menciptakan kondusif belajar peserta didik di Madrasah Tsanawiyah (MTs) Muhammadiyah Nusa Puan adalah menekankan atuaran tata tertib dan suguhan ilmu-ilmu keislaman yang membuat peserta didik memiliki sikap disiplin sehingga dijadikan sebagai training untuk melatih peserta didik agar disiplin dan bertanggung jawab dan taat pada ajaran agama yang dipelajari. Adapun upaya yang saya lakukan adalah dengan menerapkan hukuman kepada peserta didik seperti bila ia terlambat dan jika ia tidak mengerjakan tugas yang saya berikan dan dia tidak mengerjakannya maka saya akan memberikan hukuman berupa teguran baik secara lisan dan memberikan surat kepada orang tua peserta didik, sehingga dengan sendirinya akan timbul rasa tanggung jawab dan disiplin untuk membantu karakter peserta didik itu sendiri.

Senada yang diungkapkan oleh guru BK bahwa upaya untuk menciptakan tata tertib dalam menimbulkan sikap disiplin demi terciptanya 
kondisi belajar yang kondusif, sebagaimana yang diungkapkan oleh guru BK berikut:

Untuk memenuhi penanaman nilai-nilai pendidikan agama islam yang ada di Madrasah Tsanawiyah (MTs) Muhammadiyah Nusa Puan khususnya ke disiplinan hendaknya semua komponen yang ada di madrasah harus menerapkannya, sehingga dapat menjadi contoh, bagi peserta didik tidak perlu lagi diperintah atau ditegur karena sudah ada contoh yang diberikan oleh seluruh komponen yang ada di madrasah.

Hal ini dipertegas oleh guru SKI yang peneliti wawancarai mengungkapkan:

Bahwa pelaksanaan tata tertib yang diterapkan oleh pihak Madrasah Tsanawiyah (MTs) Muhammadiyah Nusa Puan, khususnya sikap ke disiplinan bukan hanya pada peserta didik tapi juga diterapkan juga pada guru, sehingga prespektif peserta didik tidak merasa terbebani, karena guru juga sebagai teladan bagi mereka, juga mematuhi tata tertib yang berlaku di Madrasah Tsanawiyah (MTs) Muhammadiyah Nusa Puan dengan rasa tanggung jawab, di mana peserta didik melaksanakan tata tertib tersebut dengan perasaan senang, penuh tanggung jawab dan kesadaran sendiri akan penting ke disiplinan bukan karena ada hukuman yang diberikan jika melanggar tata tertib tersebut.

Sedangkan menurut Kepala Madrasah Tsanawiyah

Muhammadiyah Nusa Puan yang peneliti wawancarai terhadap upayaupaya yang dilakukan oleh pihak madrasah dalam menerapkan nilai-nilai pendidikan Islam mengungkapkan:

Bahwa untuk menerapkan nilai-nilai Pendidikan Islam di Madrasah Tsanawiyah (MTs) Muhammadiyah Nusa Puan tentang berjalan dengan kondisi kondusif, maka upaya yang dilakukan oleh pihak madrasah membentuk piket untuk memantau semua komponen yang ada di madrasah. Misalnya jika ada kelas yang kosong karena guru tidak datang mengajar maka di isi oleh wali kelas,guru BK maupun saya sendiri sebagai kepala maadrasah mengisi ruang kelas tersebut, sehingga peserta didik tidak berkeliaran yang pada akhirnya akan menggangu proses pembelajaran di kelas lain. Selain mengisi kelas yang kosong upaya yang dilakukan oleh pihak madrasah dalam memberikan kopian tentang materi-materi keislaman maupun diberikan nasehat pada peserta didik, sehingga dampak penanaman nilai-nilai pendidikan Islam tersebut berdampak pada diri peserta didik di mana lancarnya proses 
pembelajaran, patuhnya peserta didik terhadap gurunya dan terciptanya sifat menyayangi antar peserta didik yang ada di Madrasah Tsanawiyah (MTs) Muhammadiyah Nusa Puan.

Dari hasil wawancara di atas penulis dapat menyimpulkan bahwa penanaman nilai-nilai pendidikan Islam dapat membentuk karakter sikap disiplin, tanggung jawab dan karakter lain dapat menciptakan suasana yang kondusif. dalam menekankan tata tertib sebagai upaya guru, maka guru juga melakukan upaya-upaya lain dalam proses pembelajaran, sebagaimana yang diungkapkan oleh informan guru ahkida akhlak yang peneliti wawancarai mengungkapkan:

Dalam proses pembelajaran maka yang saya lakukan setiap kelas itu berbeda cara mengajar saya terlebih dahulu saya melihat kondisi kelas tersebut, contohnya saya menjelaskan terlebih dahulu dan meminta tanggapan dari peserta didik, atau saya memberikan soal-soal terlebih dahulu dan baru memasuki inti pelajaran.

Efektivitas dan efisiensi yang dimaksud di sini adalah sebagaimana hasil pengamatan dalam mengikuti secara langsung proses belajar mengajar di kelas. Bahwa seorang guru memberikan materi pelajaran mampu menjelaskan masalah-masalah yang kurang dan belum dipahami peserta didik secara langsung. Guru menjawab/menjelaskan pertanyaanpertanyaan peserta didik berdasarkan masalah

\section{Faktor Pendukung dan Penghambat Efektivitas Tata Tertib}

Berdasarkan hasil penelitian yang Peneliti lakukan melalui wawancara dengan guru Akidah Ahklak dan Peserta didik, Peneliti mendapat jawaban tentang faktor-faktor yang mempengaruhi efektivitas Tata tertib yaitu terdapat faktor pendukung dan penghambat.

a. Faktor Pendukung

Dalam pemberian tugas kepada peserta didik memang bukan merupakan kegiatan yang mudah. Dalam perwujudannya memerlukan banyak faktor pendukung untuk memperoleh hasil yang optimal dalam membentuk peserta didik yang bertanggung jawab. Kesabaran dan 
semangat merupakan kunci yang utama untuk melalui tahapan-tahapan dalam mengenalkan dan membiasakannya.

Berdasarkan wawancara yang disampaikan oleh Guru BK yang menjelaskan bahwa faktor pendukung dalam pembelajaran PAI dengan menggunakan metode tugas 1) Pendidik, yang merupakan tenaga ahli dan profesional. Tugas pendidik adalah memberikan pengajaran dan bertanggung jawab dalam membentuk dan membimbing sikap dan tingkah laku peserta didik; 2) Pendekatan belajar dan pengorganisasian belajar. 3) Sarana dan prasarana sebagai penunjang dalam pembelajaran; dan 4) Buku-buku PAl, yang digunakan guru sebagai bahan dalam memberi tugas.

Dari pendapat di atas dapat disimpulkan bahwa faktor-faktor yang mempengaruhi proses ektifitas peserta didik salah satunya yaitu adanya faktor pendukung seperti pendekatan belajar, pengorganisasian belajar, guru/pendidik, sarana dan prasarana, serta memiliki buku-buku Islami. Dengan adanya faktor pendukung ini diharapkan membantu dalam mendidik karakter peserta didik.

\section{b. Faktor Penghambat}

Faktor penghambat merupakan sesuatu yang tidak terlepas dalam suatu program atau kegiatan, jalan itu tidak selalu lurus dan mulus, pastinya ada belokan, lubang dan kerikil yang menghiasinya. Begitu pula dalam efektivitas tata tertib di MTs Muhammadiyah Nusa Puan juga menemukan beberapa penghambat, seperti yang dipaparkan oleh guru SKI yang menyatakan bahwa faktor penghambat adalah:

1) kondisi kesehatan tubuh, tubuh yang lemah dan mudah sakit dapat menurunkan kualitas belajar.

2) latar belakang siswa, keluarga merupakan lingkungan pertama dalam perkembangan keagamaan pada anak, jika dalam keluarga menunjukan sikap dan tingkah laku yang baik atau buruk, maka akan berpengaruh terhadap pembentukan kepribadian anak;

3) Konsentrasi anak yang mudah berubah-ubah/tidak fokus, seperti persoalan keluarga misal adanya pertengkaran orang tua di rumah, orang tua yang pergi ke luar negeri, dan sebagainya; dan Lingkungan belajar, seperti kondisi kelas yang kotor, dan ada anak yang bermasalah misal sering terlambat, tidak pernah mengerjakan tugas, suka berkelahi, dan suka berbuat onar di kelas.

Berdasarkan pendapat di atas dapat disimpulkan bahwa, faktor penghambat dalam efektifitas tata tertib dengan pemberian tugas yaitu 
latar belakang peserta didik, dimana peserta didik berangkat dari keluarga yang berbeda-beda, ada yang dari keluarga yang agamis dan keluarga non agamis, ada orang tua yang selalu memperhatikan dan membiasakan belajar anak ketika di rumah dan ada pula orang tua yang acuh terhadap anak. Ini bisa berpengaruh terhadap peserta didik ketika di sekolah, 2) Peserta didik mudah tidak fokus, contohnya peserta didik yang kurang tidur, dan berbagai masalah dalam keluarganya, misalnya pertengkaran antar orang tua ini berpengaruh terhadap sikap anak dalam belajar, dan 3) Lingkungan belajar, seperti kondisi kelas yang kurang rapi sehingga membuat anak kurang nyaman dalam belajar.

Dalam menggunakan suatu metode pada mata pelajaran guru menggunakan metode pemberian tugas sesuai dengan pernyataannya bahwa selain menggunakan metode ceramah dan bercerita guru menggunakan metode pemberian tugas sebagai salah satu langkah untuk mencapai tujuan dalam pembelajaran pendidikan agama Islam, dimana temanya disesuaikan dengan materi ajarnya atau sub tema yang dipelajari.

Dalam dunia pendidikan semua mengetahui bahwa tugas guru bukan hanya mengajar dan memberi ilmu pengetahuan saja kepada anak didik tetapi lebih dari itu yakni membina kepribadian peserta didik menjadi mandiri sehingga terciptalah kepribadian yang baik dan bisa bertanggungjawab.

Berdasarkan paparan di atas, guru SKI menyatakan bahwa dalam proses belajar mengajar dikelaspun apabila ada salah satu peserta didik yang berlaku tidak baik dan membuat gaduh kelas atau berbicara sendiri maka guru akan menegurnya, pemberian hukuman juga penekanannya pada pembelajaran SKI yaitu berupa didikan misalnya membaca ayat AIQur'an beserta artinya. Hal tersebut guru lakukan supaya peserta didik selalu bertanggungjawab dengan tugas yang telah guru berikan. Dimana dengan selalu mengerjakan tugas merupakan cara untuk membentuk kepribadian peserta didik yang tekun dan bertanggung jawab. 


\section{4) Upaya-Upaya yang Dilakukan Guru dalam Menciptakan Kondisi Belajar yang Efektif.}

Arahan dari kepala MTs Muhammadiyah Nusa Puan, bahwa guru dalam melaksanakan kegiatan pembelajaran di kelas hendaknya senantiasa menekankan penerapan tata tertib di kelas sebelum proses pembelajaran dimulai. Dalam proses pembelajaran yang dilakukan oleh seorang guru dalam menciptakan kondisi belajar yang efektif maka yang diupayakan oleh guru dengan menekankan tata tertib yang dilakukan oleh seorang guru dalam proses pembelajaran. Dalam menciptakan kondisi pembelajaran yang kondusif di MTs Muhammadiyah Nusa Puan lebih menekankan kepada ke disiplinan dan mematuhi aturan yang diterapkan pihak madrasah kepada peserta didik, sebagaimana yang diungkapkan oleh informan yang peneliti wawancarai sebagai berikut:

"Dalam menciptakan kondusif belajar peserta didik di MTs Muhammadiyah Nusa Puan adalah menekankan atuaran tata tertib yang membuat peserta didik memiliki sikap disiplin dan dijadikan sebagai training untuk melatih peserta didik untuk disiplin dan bertanggung jawab. Adapun upaya yang saya lakukan adalah dengan menerapkan hukuman kepada peserta didik seperti biasa bila ia terlambat dan jika ia tidak mengerjakan tugas yang saya berikan, saya akan memberikan hukuman berupa teguran baik secara lisan dan memberikan surat kepada orang tua peserta didik."

Hal ini dipertegas oleh guru SKI yang peneliti wawancarai mengungkapkan:

"Bahwa pelaksanaan tata tertib yang diterapkan oleh pihak MTs Muhammadiyah Nusa Puan khususnya sikap ke disiplinan bukan hanya pada peserta didik tapi juga diterapkan juga pada guru, sehingga prespektif peserta didik tidak merasa terbebani, karena guru juga sebagai teladan bagi mereka, juga mematuhi tata tertib yang berlaku di MTs Muhammadiyah Nusa Puan dengan rasa tanggung jawab, di mana peserta didik melaksanakan tata tertib tersebut dengan perasaan senang, penuh tanggung jawab dan kesadaran sendiri akan penting ke disiplinan bukan karena ada hukuman yang diberikan jika melanggar tata tertib tersebut". 
Sedangkan menurut Kepala MTs Muhammadiyah Nusa Puan yang peneliti wawancarai terhadap upaya-upaya yang dilakukan oleh pihak madrasah dalam menciptakan kondisi belajar efektif mengungkapkan:

"Bahwa untuk menciptakan kondisi pembelajaran di MTs Muhammadiyah Nusa Puan tentang berjalan dengan kondisi kondusif, maka upaya yang dilakukan oleh pihak madrasah membentuk piket untuk memantau semua komponen yang ada di madrasah. Misalnya jika ada kelas yang kosong karena guru tidak datang mengajar maka di isi oleh wali kelas, guru BK maupun saya sendiri sebagai kepala maadrasah mengisi ruang kelas tersebut, sehingga peserta didik tidak berkeliaran yang pada akhirnya akan menggangu proses pembelajaran di kelas lain".

Selain mengisi kelas yang kosong upaya yang dilakukan oleh pihak madrasah dalam memberikan kopian tentang tata tertib yang berlaku, sehingga dampak tata tertib tersebut berdampak pada diri peserta didik di mana lancarnya proses pembelajaran, patuhnya peserta didik terhadap gurunya dan terciptanya sifat menyayangi antar peserta didik yang ada di MTs Muhammadiyah Nusa Puan.

Dari hasil wawancara di atas penulis dapat menyimpulkan bahwa tata tertib itu membentuk karakter sikap disiplin, tanggung jawab dan karakter lain dapat menciptakan suasana belajar yang kondusif. Selain menekankan tata tertib sebagai upaya guru dalam menciptakan kondisi belajar, maka guru juga melakukan upayaupaya lain dalam proses pembelajaran.

Efektivitas dan efisiensi yang dimaksud di sini adalah sebagaimana hasil pengamatan kami dalam mengikuti secara langsung proses belajar mengajar di kelas. Bahwa seorang guru memberikan materi pelajaran mampu menjelaskan masalah-masalah yang kurang dan belum dipahami peserta didik secara langsung. Guru menjawab/menjelaskan pertanyaanpertanyaan peserta didik berdasarkan masalah yang berkaitan dengan materi pelajaran setiap sub-sub pokok materi pelajaran, dengan kembali menampilkan slideny.

\section{PEMBAHASAN}




\section{Efektifitas Tatat tertib dalam meningkatkan efektifitas peserta didik di MTs Muhammadiyah Nusa Puan}

Keberhasilan guru dalam meningkatkan efektivitas belajar peserta didik sangat dipengaruhi oleh tata tertib yang diterapkan oleh kepala sekolah serta guru yang ditunjang oleh peran serta peserta didik dalam mematuhi aturan yang telah dibuat oleh seluruh komponen yang ada di madrasah, tata tertib yang diberlakukan oleh kebijakan madrasah berlaku di lingkungan madrasah baik pada waktu proses pembelajaran berlangsung maupun di luar proses pembelajaran, tata tertib senantiasa ditaati oleh seluruh komponen yang ada di MTs Muhammadiyah Nusa Puan.

Peneliti sebelum mendeskripsikan tentang peranan tata tertib peserta didik yang terdapat dalam proses pembelajaran, terlebih dahulu menjelaskan tentang gambaran awal tahapan proses pembuatan tata tertib di MTs Muhammadiyah Nusa Puan. MTs Muhammadiyah Nusa Puan sebagai salah satu lembaga pendidikan formal setingkat sekolah lanjutan tingkat pertama yang berada di bawah garis koordinasi pada Kementrian Agama Republik Indonesia memiliki tata tertib dalam proses pembelajarannya yang menjadi ciri kekhasan madrasah.

Peneliti pada wawancara dengan kepala Mts Muhammadiyah Nusa Puan, Kabupaten Seram Bagian Barat mendapat informasi menyatakan bahwa penyusunan tata tertib di Mts Muhammadiyah Nusa Puan berdasarkan masukan dari semua yang ada, sehingga tata tertib tersebut dapat diterapkan pada peserta didik. Dengan adanya tata tertib yang di buat oleh pihak madrasah menjadi acuan bagi semua peserta didik untuk senantiasa mematuhinya.

Tata tertib yang dijalankan oleh pihak MTs Muhammadiyah Nusa Puan senantiasa dilakukan secara bertahap dengan terlebih dahulu ada sosialisasi yang diberikan oleh guru dalam hal ini dibebankan oleh Guru BK(bimbingan konseling) sebagaimana yang diungkapkan dari hasil wawancara oleh informan pada peneliti mengungkapkan sebagai berikut: 
"Pelakasanaan tata tertib yang diterapkan di MTs Muhammadiyah Nusa Puan senantiasa disosialisasikan oleh pihak madrasah terutama pada saat upacara bendera".

Peranan tata tertib yang diterapkan pada peserta didik memiliki peran yang sangat penting dalam peningkatan disiplin peserta didik dan motivasi belajar semakin tinggi sebagaimana yang diungkapkan oleh nara sumber yang bernama Amat Hitimala mengungkapkan:

"Dengan diterapkannya tata tertib yang ada di madrasah berdampak padapeningkatan akademik saya dimana pada nilai rapor saya pada semeseter yang lalu mengalami peningkatan yang signifikan, disamping itu dengan adanya tata tertib yang diterapkan dimadrasah membuat saya semakin disiplin dan juga berdampak pada kegiatan ekstrakurikuler yang saya lakukan".

Hal tersebut senada yang diungkapkan Irmasyah Putra dari hasil wawancara yang peneliti lakukan sebagai berikut:

"Penerapan tata tertib yang diterapkan di Madrasah Tsanawiyah Negeri (MTsN) Tinambung itu memberi dampak positif bagi peserta didik, dimana pada saat peserta didik melanggar aturan yang telah ditentukan akan mendapatkan sanksi, itu akan membuat peserta didik akan berubah sikap dan perilakunya sehingga berdampak pada hasil belajar peserta didik tersebut".

Peneliti menilai tata tertib yang diterapkan oleh pihak MTs Muhammadiyah Nusa Puan memiliki peranan yang sangat penting bagi peserta didik seperti kepatuhan peserta didik dalam proses pembelajaran, dan pengembangan kebiasaan-kebiasaan peserta didik ke arah yang lebih positif. Di sisi lain, sejak diterapkannya tata tertib di madrasah banyak peserta didik yang mendapatkan sanksi dari pihak madrasah dengan memanggil orang tua peserta didik untuk datang ke Madrasah.

Sedangkan esensi dari dasar penerapan tata tertib di madrasah agar semua peserta didik menaatinya demi kepentingan peserta didik tersebut agar terbentuk sikap disiplin dan bertanggung jawab. Tata tertib yang dibuat oleh pihak madrasah tidak semua ditaati oleh peserta didik ada saja peserta didik yang melanggar sebagaimana yang diungkapkan oleh peserta didik bernama Rahmawati: 
Tata tertib yang di terapkan pada MTs Muhammadiyah Nusa Puan, masih ada peserta didik yang melanggarnya. Saya sendiri pernah melanggar aturan tersebut seperti datang terlambat ke madrasah.

Sedangkan menurut guru BK dari wawancara dari peneliti mengungkapkan:

"Bahwa tata tertib mempunyai peran sangat penting dalam pengembangan kepribadian bagi peserta didik. Dimana dengan tata tertib peserta didik dapat terarah, karena peserta didik dapat melihat yang mana dapat dilakukan dan mana yang tidak dapat dilakukan di madrasah".

Dari hasil wawancara yang peneliti lakukan dapat menyimpulkan bahwa tata tertib telah diterapkan di MTs Muhammadiyah Nusa Puan dimana bagi peserta didik yang melakukan pelanggaran dari tata tertib yang telah ditetapkan oleh pihak madrasah akan dikenakan hukuman atau sanksi baik itu sifatnya teguran secara lisan, hukuman dalam bentuk fisik maupun dalam bentuk mengirim surat kepada orang tua peserta didik. Walaupun tata tertib telah diterapkan ada saja peserta didik yang tetap melakukan pelanggaran, hal ini disebabkan oleh karakteristik oleh peserta didik yang masih dalam tahap pencarian jati diri.

Dalam menerapkan tata tertib pada peserta didik sehingga peserta didik menjadikannya tata tertib sebagai karakter dalam dirinya, itu membutuhkan sikap kesabaran dan keteladanan setiap guru dan pihak yang ada di MTs Muhammadiyah Nusa Puan agar dapat menerapkan tata tertib yang ada sehingga peserta didik dapat menaati aturan yang telah diterapkan di MTs Muhammadiyah Nusa Puan demi pembentukan karakterpeserta didik itu sendiri. Tata tertib merupakan masalah yang urgen dalam kehidupan manusia, termasuk di MTs Muhammadiyah Nusa Puan, karena menjadi sesama, tanggung jawab, dan dapat berinteraksi secara harmonis aturan dalam pembentukan sikap peserta didik. Proses pembelajaran di madrasah ditentukan sampai sejauh mana tata tertib itu diterapkan dan dipatuhi. 
Peranan tata tertib sangat berkontribusi terhadap efektivitas pembelajaran yang ada sehingga berdampak pada prestasi akademik peserta didik itu sendiri. Oleh karena itu setiap komponen yang ada di Madrasah berkewajiban untuk mematuhi aturan yang telah di buat. Oleh karena itu, betapa pentingnya tata tertib di terapkan di madrasah karena mempunyai peran yang sangat penting dalam pembentukan karakter dan efektivitas belajar peserta didik. Hal ini sesuai dengan hasil wawancara dari narasumber yang ada di MTs Muhammadiyah Nusa Puan.

Tata tertib merupakan masalah yang urgen dalam kehidupan bagi manusia tak terkecuali dunia pendidikan dimana didalamnya ada peserta didik, karena menjadi penentu efektivitas peserta didik dalam proses pembelajaran (E Mulyasa, 2018:79). Efektif tidaknya proses pembelajaran ditentukan oleh berjalan tidaknya tata tertib yang telah di buat oleh pihak madrasah. Proses pembelajaran efektif ditentukan oleh bagaimana penerapan aturan yang telah di buat oleh pihak madrasah maupun semua stake holder yang ada dalam merumuskan tata tertib yang akan diterapkan oleh pihak madrasah.

Penyusunan tata tertib yang dibuat oleh pihak madrasah merupakan acuan bagi pihak madrasah dalam menerapkan aturan yang diberlakukan sebagai mana yang hasil wawancara terhadap oleh Kepala MTs Muhammadiyah Nusa Puan. Sehingga untuk mengetahui efektifitas tata tertib dalam mengimplementasikan nilai-nilai pendidikan Islam dari dua faktor antara lain faktor penghambat dan faktor pendukung.

\section{Faktor penghambat dan Pendukung Efektifitas tata tertib pada peserta didik di MTs Muhammadiyah Nusa Puan}

Berdasarkan hasil penelitian yang Peneliti lakukan melalui wawancara dengan guru BK dan Peserta didik, Peneliti mendapat jawaban tentang faktor-faktor yang mempengaruhi efektivitas pembelajaran BK dengan menggunakan metode tugas yaitu terdapat faktor pendukung dan penghambat:

a. Faktor Pendukung 
Dalam pemberian tugas BK kepada peserta didik memang bukan merupakan kegiatan yang mudah. Dalam perwujudannya memerlukan banyak faktor pendukung untuk memperoleh hasil yang optimal dalam membentuk anak didik yang bertanggung jawab. Kesabaran dan semangat merupakan kunci yang utama untuk melalui tahapan-tahapan dalam mengenalkan dan membiasakannya. Berdasarkan wawancara yang disampaikan oleh Guru BK, yang menjelaskan bahwa faktor pendukung dalam pembelajaran BK dengan menggunakan metode tugas 1) Pendidik, yang merupakan tenaga ahli dan profesional. Tugas pendidik adalah memberikan pengajaran dan bertanggung jawab dalam membentuk dan membimbing sikap dan tingkah laku peserta didik; 2) Pendekatan belajar dan pengorganisasian belajar. 3) Sarana dan prasarana sebagai penunjang dalam pembelajaran; dan 4) Buku-buku BK, yang digunakan guru sebagai bahan dalam memberi tugas. Efektifitas tata tertib dalam mengimplementasikan nilai-nilai islam dapat di ketahui melalui tiga hal diantaranya:

1) Faktor pendidik, dalam suatu lembaga atau sekolah pendidik sangat berperan penting dalam menjalan tata tertib yang ada dalam lembaga tersebut, seperti Pendidik yang ada di Mts Muhammadiya Nusa Puan yang selalu menjalankan tata tertib sesuai anjuran Mts, bahkan mengenai tata tertib pendidik dapat mengimplemetasikan ke kehidupan sehari-hari.

2) Faktor sarana dan prasarana, sarana dan prasarana dikaitkan dengan lingkungan sekolahan dalam tata tertib di Mts Muhammadiyah Nusa Puan.

3) Peserta didik, karena tidak semua peserta didik yang lebih tertib pada tata tertib dalam mengimplementasi nilai-nilai pendidikan islam.

b. Faktor Penghambat

Faktor penghambat merupakan sesuatu yang tidak terlepas dalam suatu program atau kegiatan, jalan itu tidak selalu lurus dan mulus, 
pastinya ada belokan, lubang dan kerikil yang menghiasinya. Begitu pula dalam efektivitas pembelajaran BK dengan menggunakan metode tugas di Mts Muhammadiyah Nusa Puan juga menemukan beberapa penghambat, seperti yang dipaparkan oleh guru BK yang menyatakan bahwa faktor penghambat pelaksanaan metode tugas dalam pembelajaran Akidah Akhlak:

1) kondisi kesehatan tubuh, tubuh yang lemah dan mudah sakit dapat menurunkan kualitas belajar.

2) latar belakang peserta didik, keluarga merupakan lingkungan pertama dalam perkembangan keagamaan pada anak, jika dalam keluarga menunjukan sikap dan tingkah laku yang baik atau buruk, maka akan berpengaruh terhadap pembentukan kepribadian anak;

3) Konsentrasi anak yang mudah berubah-ubah/tidak fokus, seperti persoalan keluarga misal adanya pertengkaran orang tua di rumah, orang tua yang pergi ke luar negeri, dan sebagainya.

4) Lingkungan belajar, seperti kondisi kelas yang kotor, dan ada anakanak yang bermasalah misal sering terlambat, tidak pernah mengerjakan tugas, suka berkelahi, dan suka bikin onar di kelas.

Berdasarkan pendapat di atas dapat disimpulkan bahwa, faktor penghambat dalam pembelajaran BK dengan pemberian tugas yaitu: 1) latar belakang peserta didik, dimana peserta didik berangkat dari keluarga yang berbeda-beda, ada yang dari keluarga yang agamis dan keluarga non agamis, ada orang tua yang selalu memperhatikan dan membiasakan belajar anak ketika di rumah dan ada pula orang tua yang acuh terhadap anak. Ini bisa berpengaruh terhadap peserta didik ketika di sekolah, 2) Peserta didik mudah tidak fokus, contohnya peserta didik yang kurang tidur, dan berbagai masalah dalam keluarganya, misalnya pertengkaran antar orang tua ini berpengaruh terhadap sikap anak dalam belajar, dan 3) Lingkungan belajar, seperti kondisi kelas yang kurang rapi sehingga membuat anak kurang nyaman dalam belajar. 
Jadi untuk mengetahui faktor penghambat efektifitas tata tertib dalam mngimplementasikan nilai-nilai pendidikan Islam di Mts Muhammadiyah Nusa Puan Sebagai berikut:

1) faktor internal dari peserta didik yang beberapa orang memahami tata tertib dengan baik.

2) faktor external, dari lingkungan maupun masyarakat

\section{KESIMPULAN}

Efektifitas merupakan serangkaian kegiatan yang dilaksanakan oleh guru dan peserta didik dengan memanfaatkan sarana yang tersedia untuk memperoleh hasil belajar secara optimal. Efektivitas tata tertib merupakan suatu ukuran yang menyatakan seberapa jauh target kuantitas maupun kualitas yang telah tercapai. Dalam proses pelaksanaan tata tertib di MTs Muhammadiyah Nusa Puan memuat berbagai kegiatan dan pelajaran baik yang dilaksanakan di dalam kelas maupun di luar kelas dan dengan berbagai macam metode, seperti metode ceramah, diskusi, dan metode tugas.

Hasil penelitian ini menunjukan bahwa 1). efektivitas tata tertib dalam mengimplementasikan nilai-nilai pendidikan islam di MTs Muhammadiyah Nusa Puan sudah efektif. Sebagai bukti bahwa proses tata tertib pada nilai-nilai Islam itu efektif yaitu melalui, sarana dan media yang digunakan, serta sikap peserta didik dalam mempertanggung jawabkan nasehat yang diberikan oleh Guru. 2). faktor pendukung. (a. pendidik dalam menerapkan tata tertib sesuai dengan mengimplementasikan nilai-nilai pendidikan islam, b. pendidik, hampir semua dapat mengimplementasikan pada tata tertib yang sesuai c. sarana dan prasarana, dibuktikan dengan lingkungan sekolah pada tata tertib), 3) faktor penghambat: (a. faktor internal dari peserta didik yang beberapa orang memahami tata tertib dengan baik, b. faktor external, dari lingkungan maupun masyarakat).

\section{DAFTAR PUSTAKA}


[1] Ahnah Tanzeh. Metode Penelitian Praktis. PT Bina IImu. Jakarta pusat.2004.

[2] Arif Furchan, Pengantar Metodologi Penelitian Kualitatif, Surabaya Usaha Nasional,1992.

[3] Bungin Burhan, Metodologi Penelitian Sosial, Surabaya Airlangga University Prees.

[4] Burhan Bungin, Analisis Data Penelitian Kualitatif Pemahaman Filosofis dan Cipta, 2002.

[5] Elizabeth B. Hurlock, Psikologi Perkembangan Suatu Pendekatan Sepanjang Rentang Kehidupan, Jakarta: Erlangga.

[6] H.B.Siswanto Pengantar Manajemen.

[7] Madya Eko Susilo Metologis ke Arah Penguasaan Model Aplikasi, (Jakarta: Raja Grafindo Persada, 2003.

[8] Moeleong J.Lexy. Metode Penelitian kualitatif. Bandung PT Remaja Rosdakarya.

[9] Ridwan Metode dan Teknik Menyusun Proposal Penelitian

[10] Ridwan, Statistika Untuk Lembaga dan Instansi Pemerintah/Swasta, Bandung Alfabeta, 2004.

[11] Sugiyono, Metode Penelitian Kuantitatif Kualitatif dan R\&D.

[12] Suharsimi Arikunto Prosedur Penelitian Suatu Pendekatan praktek.

[13] Sukandar, Rumidi, "Metodologi Penelitian Petunjuk praktik Untuk Peneliti Pemula".

[14] Suryosubroto, Manajemen Pendidikan di Madrasah. 